\title{
Research on Moral Education Value of Steel Spirit Culture
}

\author{
Ming $\mathrm{He}$ \\ Graduate School \\ Wuhan University of Science and Technology \\ Wuhan, China
}

\begin{abstract}
There are still moral misconduct behaviors and performances among college students, which is still far from the talent cultivation concept of strengthening moral education and cultivating people in colleges and universities. It is very important to strengthen and improve college students' moral education practice innovation under the new situation. This paper explores the educational value of steel culture in the practice of moral education from the perspectives of "passing the steel quality, appreciating historical relics, excavating excellent craftsmen, and experiencing the process of smelting". It aims to give play to the "leading value, spreading value, inspiring value and practical value" of steel spirit culture.
\end{abstract}

Keywords-steel spiritual culture; moral education of college students; educational value research

\section{INTRODUCTION}

There are still moral abnormality behaviors and performances such as "empty talk about ideals, weak responsibilities, and lack of etiquette" among college students. Colleges and universities often rely on the first class of moral education of "entrance education", and multisubjects [1] conduct systematic education and achieve good results from different content systems [2]. Under the new situation, colleges and universities must adapt to the development needs of the socialist economy, pay attention to the outstanding problems of the current college students' moral education, correctly grasp the educational laws of moral education in colleges and universities, and continue to strengthen and improve the moral education practice innovation of college students.
*Funds: "Steel spirit thematic education and moral education practice of postgraduates in metallurgy university" of practical education special program of colleges and universities in 2017 in Hubei province (Project No 2017SJJPC3010); "Exploration and practice of the practical education system for full-time professional degree postgraduates" of postgraduate quality engineering project in 2017 of Wuhan University of Science and Technology (Project No. Yjg201722)

\section{STRENGTHENING AND IMPROVING THE IMPORTANCE OF COLLEGE StUdENTS' MORAL EDUCATION PRACTICE INNOVATION}

\section{A. Historical Requirements for the Development and Evolution of Multiculturalism in the Context of Economic Globalization}

Under the tide of economic globalization, various ideological and cultural cultures are intertwined and collided. The overall situation of college student group is positively and upwardly. With the rapid acceleration of new media communication, the channels of information acquisition have expanded rapidly. Western decadent ideas, such as money worship, individualism, and hedonism, have prevailed in online media. Western culture uses their ethical standards and value orientation to influence and even erode the morality of contemporary college student. They are in a period of growth in which their ideological situation is unstable, their political beliefs are not firm, and their national consciousness is weak. They are more vulnerable to negative influences from social and international bad thoughts, and their values and behaviors have gradually changed. Some college students turn a deaf ear to the ideological and political theory courses in colleges and universities, do not care about the mainstream culture of contemporary society, and even lose confidence in the ideals and goals of socialism. Facing the historical requirements of the development and evolution of multiculturalism in the context of economic globalization, it is necessary to strengthen and improve the practice and innovation of college students' moral education, and completely eliminate the moral abnormality such as the rise of hedonism, the dilution of collectivism and the prevalence of self-interest. It is of far-reaching historical significance to consolidate the important position of socialist core values in the field of campus ideology, and guide young college students to speak up, respect and observe morality and pursue noble moral ideals.

\section{B. Cultivating and Carrying Forward the Requirements of the Times of Socialist Core Values in the New Era}

The core value of socialism is the embodiment of the spirit of the Chinese nation and embodies the common values pursued by the Chinese compatriots. The basic content of its four aspects is interconnected and connected 
and constitutes a dialectical and unified organic whole. Objectively, there is such a scientific and comprehensive, standardized and complete moral education system that constantly adapts to the development and changes of the new situation, and guarantees that the socialist core value system always runs through the whole process of college students' ideological and moral education. General Secretary Xi Jinping pointed out, "The core values are actually a kind of morality, which is not only a personal virtue, but also a great virtue. It is the virtue of the country and the virtue of society." [3] To practice the core values of socialism, it is necessary to strengthen ideological and moral development, set up the right value orientation, and form a good social civilization. In order to comply with the requirements of social development for the core values of the times, colleges and universities must closely focus on the fundamental tasks of strengthening moral education and cultivating people and incorporate the socialist core values into the overall planning of national education. In the whole higher education field from education and teaching to management services, it is necessary to carry out moral education activities with the theme of loving learning and labor, loving the motherland and the people, and forming a moral education teaching and practice system integrating classroom teaching, social practice and campus culture, so as to continuously improve the educational effectiveness of China's excellent traditional culture, and form a scientific and effective moral education mechanism.

\section{The Task Requirements for Cultivating Socialist Construction Builders and Successors in Colleges and Universities}

"Strengthening and improving the ideological and political work of colleges and universities, the fundamental issue of running what kind of universities and how to run them are major political tasks and strategic projects concerning the party's leadership over colleges and universities, and the succession of the cause of socialism with Chinese characteristics. [4] As a talent training position, colleges and universities shoulder the responsibility and mission of innovative ideological and political education, research on advanced ideology and culture, and dissemination of noble values. As stated in "The Book of Rite - Daxue", "Great Learning aims to foster moral integrity, forge close ties with the people and attain consummate virtue in both words and deeds". The ancients believed that everyone has the talent and character of a person who can develop virtue, but not everyone will have a sense of conscious practice. The talents cultivated by colleges and universities must be "excellent" talents who are loyal to the party, loyal to the country, and loyal to the people. Whether the talents exported are qualified is related to the success or failure and long-term development of China's socialist reform. A country without virtue will not flourish, and a man without virtue will not stand. Strengthening and improving the practice and innovation of college students' moral education, taking the concept of strengthening moral education and cultivating people as the first priority of cultivating talents in colleges and universities, insisting on educating people and moral education as the first, and cultivating qualified builders and successors with high political consciousness and outstanding professional ability can the Chinese dream of great national rejuvenation be realized.

\section{The Inevitable Requirement for the Development of Individual Comprehensive Quality of College Students in the New Era}

At present, college students born and grow in a new era of rapid development of market economy and diversified values. The diverse social needs and the intertwined interests make the college students' world outlook, outlook on life and values be diverse and individual. Their value orientation develops in multiple dimensions. They have a strong sense of innovation, prefer to accept new things and new ideas, and are good at acquiring outside information through various new media methods. Their money-raising ideas are becoming more and more serious. They pay more attention to material enjoyment in their work and life, focus on economic value and power value, and have a weak sense of honesty and lack of social responsibility. Facing the new characteristics and new demands of college students, colleges and universities must adjust and enrich the content of moral education system in a timely manner. It is necessary to cultivate the individual comprehensive quality of college students, and to train students to work hard and positively and optimistically, so as to promote the all-round growth and development of college students. The goal of moral education in colleges and universities is to enable students to "work hard to serve the people, have the spirit of hard work and a strong sense of mission and responsibility", "consciously abide by the law and discipline, have a good moral quality and a healthy psychological quality" [5]. Strengthening and improving college students' practice and innovation of moral education is to continuously improve students' ideological level, political consciousness, moral quality and cultural accomplishment. The colleges and universities should care for students and serve students in study and life, and strive to make young college students become compound intellectual talents with political consciousness and moral quality.

\section{RESEARCH ON THE VALUE OF STEEL SPIRITUAL Culture In the Process of College Students' Moral EDUCATION}

\section{A. Inheriting the Quality of Steel and Exerting the Value of Fortitude Spirit in the Process of Moral Education}

Good moral quality is the essence of a person distinguishing from that of other animals, and is the basis of a person's ability to stand in society. Einstein believes that "excellent character and the will of steel are more important than wisdom and erudition." Rich knowledge systems are indispensable for cultivating high-quality innovative talents, but good moral quality is more important. It is the fertile ground for self-growth and the cornerstone of selfdevelopment. Metallurgical colleges should hold the great banner of steel spirit, draw on the cultural essence of steel spirit in the construction of school spirit, integrate the steel 
spirit into all aspects of schooling ideas and educational concepts, and use various media carriers such as campus broadcasting and campus windows to inherit and publicize the spirit of steel, and engrave the classic sayings embodying the spirit of steel on the road signs of the campus, create a distinctive campus culture atmosphere with steel spirit, actively carry out rich and colorful campus cultural activities, making the steel spirit culture a common pursuit of value ideas and beliefs for teachers and students. Deeply excavating and carrying forward the cultural connotation of the steel spirit of metallurgical colleges and universities, and making good use of the spiritual strength of steel quality have a spiritual leading role in cultivating socialist builders and successors with firm political consciousness and ardent party spirit.

\section{B. Appreciating Historical Relics and Giving Full Play to the Dissemination Value of Collection Materials in the Process of Moral Education}

Extensive participation in social practice and field research, appreciating the collection of historical data is also an effective way to deepen the understanding and perception of the steel spirit culture of college students. Colleges and universities should in-depth study the national moral education practice base of metallurgical system, visit and inspect some places such as Steelmaking Laboratory of Northeastern University, Archives of Beijing University of Science and Technology, History Museum of Wuhan University of Science and Technology, Wuhan Steel Museum, etc., combine with thematic education, social research and analysis, etc., give full play to the historical and cultural dissemination value of the collection materials, and guide contemporary college students to understand the inheritance and development of the steel spirit in steelmaking enterprises, deepen their ideological understanding and emotional identity, strengthen their inner self-examination, and guide them to take the example of hard-working and uncomplaining steel workers, promote their personal growth while participating in social development, stimulate their inner spiritual motivation and ethics, and help them change from an ordinary college student to the person responsible for difficult tasks and the leader of outstanding achievements. Therefore, they gradually understand themselves, improve themselves, and develop themselves.

\section{Excavating Outstanding Craftsmen and Giving Play to the Inspirational Value of the Typical Life in the Process of Moral Education}

In major steel companies, a large number of steelsmelting workers are working hard in ordinary jobs with hard work and sweat every day. They carefully guard the normal operation of the steel furnace, and they work hard to do every job day and night. They are tenacious under difficult conditions and bravely carry heavy loads in key positions. This precious quality deserves the study and indepth practice of every college student. "The role model has the charisma of personality, teach without words, and moisten things silently, reaching a state of understanding." [6] The excellent examples and the typical incentives of fresh life are endless. It is necessary to fully exploit the excellent deeds of steel workers, strengthen the cultivation of the excellent craftsmen of the enterprise, and call for and learn the hard work style of the steel workers. They not only have the quality of craftsmen with "excellence, dedication, innovation and enterprising", but also carry the spiritual wealth and excellent cultural character of the Chinese nation, which embody a high sense of professionalism and historical mission, and should become the value pursuit and the benchmark of the times of college students. Metallurgical colleges and universities should vigorously publicize the outstanding craftsmanship of steel enterprises, guide college students to learn the precious qualities, inspire young college students to face the self-confidence of difficult life, internalize the valuable character of steel workers into personal values, and promote the cultivation of moral values.

\section{Experiencing the Smelting Process and Giving Full Play to the Practical Value of Multiple Platforms in the Process of Moral Education}

"It is necessary to strengthen the ideological and moral construction of the whole society, inspire people to form good moral will, moral emotions, cultivate correct moral judgments and moral responsibilities, improve moral practice ability, especially consciously practice ability, guide people to yearn for and pursue a life of morality, respect and observance, and form the force of being upward and good." [7] The steel spirit has been passed down and developed in metallurgical colleges, and it has also been spread and continued in the steel and metallurgical industry. The experience of smelting can be carried out in classroom teaching. By reviewing the development process of human society from the "Bronze Age" to the "Iron Age", the civilization and development brought by steel smelting technology to human society will be demonstrated. On this basis, the colleges and universities impart the knowledge of steel smelting principles and methods, and encourage them to participate in the steel simulation competition based on classroom teaching and steel industry discipline competition, so as to promote students' professional development. It can also be carried out in the first line of production of steel enterprises. College students are familiar with the production processes such as "mine mining", "blast-furnace tapping" and "converter steel making", and feel "how steel is made" in an immersive way. Giving full play to the on-site education environment of steel industry, the construction of practice and moral education will be based on the inspiration of thoroughly tempered, promoting the students adult spiritually.

\section{CONCLUSION}

The historical requirements of economic globalization, the requirements of the times of core values, the task requirements of the socialist cause, and the inevitable requirements of the individual's comprehensive quality make it crucial to strengthen and improve the practice and innovation of college students' moral education. This paper explores the potential educational value of steel spiritual culture from four different perspectives, and gives play to the 
important role of steel spirit culture in the practice and innovation of moral education.

\section{REFERENCES}

[1] Ming He. the Exploration and Practice of Multi-Subject Implementation Mode in Postgraduate Entrance Education[C]. // 3rd International Conference on Education, Language, Art and InterCultural Communication.2017:241-244.

[2] Ming He. Research on Content System Constructions in Postgraduate Entrance Education in the New Era[C]. // The 2nd International Conference on Culture, Education and Economic Development of Modern Society. 2018:258-261.

[3] Xi Jinping. Building a well-off society in an all-round way and wining a great victory in socialism with Chinese characteristics in the new era - report at the 19th National Congress of the Communist Party of China [M]. Beijing: People's Publishing House, 2017: 70. (in Chinese)

[4] CPC Central Committee and State Council. Opinions on Strengthening and Improving Ideological and Political Work in Colleges and Universities in the New Situation. [EB/OL].(2017-0227)[2018-07-24]. http: //www.gov.cn/xinwen /201702/27/content_5182502.htm. (in Chinese)

[5] National Education Commission. Moral Education Outline of Chinese Ordinary Colleges and Universities [S]. Education Policy [1995] No. 11. (in Chinese)

[6] Chen Baosheng. Practically Promoting the Innovative Development of Ideological and Political Work in Colleges and Universities - Indepth Study and Implementation of the Spirit of the General Secretary Xi Jinping's Important Speech on Education [N]. Guangming Daily, 2017-08-04(01). (in Chinese)

[7] $\mathrm{Xi}$ Jinping. Speech during the inspection in Shandong [EB/OL]. (2013-11-28)[2018-07-24].http://www.gov.cn/ldhd/ 2013-11/28/ Content_2537584.htm (in Chinese) 